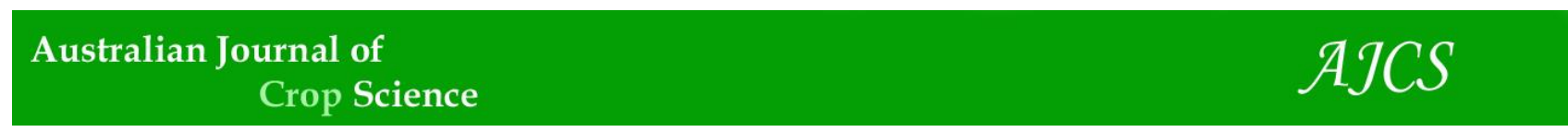

AJCS 10(12):1601-1607 (2016)

ISSN:1835-2707

doi: 10.21475/ajcs.2016.10.12.PNE58

\title{
Characterization of dissimilarity among varieties in Brazilian maize germplasm
}

\section{Diego Baretta ${ }^{1}$, Maicon Nardino ${ }^{1 *}$, Ivan Ricardo Carvalho ${ }^{1}$, Rodrigo Danielowski ${ }^{1}$, Henrique de Souza Luche $^{1}$, Victoria Freitas de Oliveira ${ }^{1}$, Velci Queiróz de Souza ${ }^{2}$, Antonio Costa de Oliveira ${ }^{3}$ and Luciano Carlos da Maia ${ }^{3}$}

${ }^{1}$ Centro de Genômica e Fitomelhoramento, UFPel, Campus Universitário, s/n, 96010-165 Capão do Leão, RS, Brasil

${ }^{2}$ Laboratório de Melhoramento Genético e Produção de Plantas, UFSM/FW, Linha 7 de Setembro, s/n, BR 386 Km 4098400-000, Frederico Westphalen, RS, Brasil

${ }^{3}$ PH. D e Dr. do Departamento de Fitotecnia, área de Fitomelhoramento da Universidade Federal de Pelotas.

\section{*Corresponding author: acostol@terra.com.br; lucianoc.maia@gmail.com}

\begin{abstract}
There is an increasing and important demand for broader qualitative and quantitative traits of agronomic characters in Brazilian maize germplasm. Nine landraces plus four commercial maize varieties and fifteen characters of agronomic importance were studied with the goal of characterizing the yield potential and genetic variability, using multivariate techniques. In fact, we aimed to identify promising sources of variability for genetic improvement. A random block design with six replications was adopted, compising of maize genotypes as treatment. Canonical discriminant analysis and Tocher's optimization clustering method, using the overall distance of Mahalanobis $\left(\mathrm{D}^{2}\right)$ as a measure of dissimilarity, were employed. Genetic dissimilarity was detected among the nine landraces and four commercial maize varieties. The characters with higher importance were: leaf angle, ear insertion height, height, grain yield, number of rows in the ear and mass of 100 grains. The hybrid AS1551, BRSPlanalto, AS3466, CD308 and the landraces populations Amarelão, Branco Roxo Índio, Caiano Rajado and Criolão presented high grain yield, indicating the importance of such varieties for maize breeding programs and/or indication of these for small farmers.
\end{abstract}

Keywords: Zea mays L., multivariate analysis, canonical discriminating analysis, genetic variability.

\section{Introduction}

The genetic variability in corn allows its cultivation in various environments. Corn is grown from latitude $58^{\circ} \mathrm{N}$ until $40^{\circ} \mathrm{S}$, extending from sea level up to $3,800 \mathrm{~m}$ atitude (Hallauer et al., 2010). The corn germplasm consists of landraces (local), adapted populations, introduced exotic populations and commercial hybrids, which contains large genetic variability. The demand was shown by breeders for more comprehensive knowledge, both qualitative and quantitative characters, on maize germplasm in Brazil. It is increasingly important, being checked by the large existing levels in commercial competitiveness for the development of cultivars (Nass et al., 1993).

The choice of germplasm is fundamental and decisive in any plant breeding program, which is aimed at the development of open pollinated varieties or obtains pure lines for use in hybridization. This fact significantly influences the success or failure of selection process.

Open populations also known as landraces contain a gene pool with high value for the improvement, since its high potential for adaptation to specific environmental conditions. Besides, they represent important source of genetic variability that can be explored in the search for genes of tolerance and/or resistance to biotic and abiotic factors (Araújo and Nass, 2002). However, the replacement of this varieties by modern hybrid cultivars, as has happened since 1950, not only just generates genetic erosion, but also threatens the knowledge of traditional farming systems (Boef, 2007).

The recovery and conservation of local varieties are of fundamental importance for the maintenance of variability of the species and to conserve genotypes in place protected from the possibility of crossings with conventional or transgenic cultivars. The cross pollination often occurs in small farms and indigenous communities due to the use of improved genotypes with greater yield potential to the crops near the landraces (Coimbra et al., 2010).

The genetic variability can be simultaneously evaluated with the use of multivariate analysis. This method can quantify many advantageous characters and is capable to determine genetic variability and new sources of genetic material (Moura et al., 1999). The more dissimilar are the parents, the greater are the resulting variability in segregating population, and the greater are the possibility of recombining alleles in transgressive segregation. More specifically, in the case of breeding populations, the more genetically distant are the populations, the greater are the results of intervarietal heterosis obtained from hybridization.

Several multivariate analyses techniques have been used to estimate the genetic dissimilaritysuch as principal component analysis, canonical discriminant analysis and agglomerative methods (Cruz et al., 2012). Several researchers have used multivariate analysis to quantify the genetic dissimilarity among genotypes and/or populations in several species. In the 
literature, there are many works with corn species, dealing with multivariate analysis (Dotto et al., 2010, Ganesan et al., 2010, Reddy et al., 2013).

This study was conducted to apply multivariate techniques to characterize the productive potential and the genetic variability in important agronomic characteristics between nine landraces and four commercial varieties of corn in order to describe the variability of populations as sources of promising genotypes for genetics breeding.

\section{Results and Discussion}

\section{Analysis of variance}

The results of the univariate variance analysis (ANOVA) of 15 important agronomic characters, in nine landraces and four commercial varieties of corn, were summarized in Table 1. It can be observed that there are significant differences ( $p$ $<0.01$ ) between the average of the 13 corn varieties for all examined characters, indicating the presence of genetic variability. Estimation of variation coefficients revealed that they were low, ranging from $3.89 \%$ for DE to $18.48 \%$ for the DE, NR performing at acceptable levels in terms of accuracy for experimental trials conducted in the field.

The occurrence of significant differences between landraces and commercial varieties was expected to some extent, given the fact that, especially hybrid commercial, have contrasting phenotypic characteristics compared to traditional varieties, resulting from selection processes applied by breeding programs. According to Cruz et al. (2012) the success of a breeding program resides in the existence of variability in the basic working population. For the formation of the population base, the interbreeding between varieties/upper and dissimilar genotypes are recommended. This difference between the varieties can be assessed from agronomic, botanical and molecular characteristics.

\section{Cluster averaged}

The results of Scott \& Knott groups for the evaluated characters are shown in Table 2. The grain yield character (GY) showed the most variability, with the formation of six group means, followed by leaf angle (LA) with five groups. Characters number of branches (NB), tassel weight (TW), insertion ear height $(\mathrm{EH})$, plant height $(\mathrm{PH})$, ear diameter (ED), number of grains rows per ear (NRE), number of grains per ear (NGE) and 100 grains weight (HGW) created four groups, succeeded by the tassel length (TL), number of grains per row (NGR) and grains weight per ear (GWE) with three groups. The stem diameter (SD) formed two groups among the varieties analyzed. The average of ageement analysis revealed the occurrence of genetic variability.

The overall mean of the experiment for the GY character was equivalent to $8742.23 \mathrm{~kg} \mathrm{ha}^{-1}$ (Table 2). The cultivars BRS Planalto (single hybrid) and AS 1551 (synthetic) presented the group with the highest average, revealing equivalent values $10,598.42$ and $10,295.40 \quad \mathrm{~kg} \mathrm{ha}^{-1}$, respectivaly. Noteworthy, is also superior performance of triple hybrid AS 3466 and double hybrid Coodetec 308 that formed the group "b" of better performance per se, with the equivalent GY values of 9,425.58 and 9,194.44 $\mathrm{kg} \mathrm{ha}^{-1}$, respectivaly. In contrast, a Caiano Rajado population showed the lowest average group, with performance of $3662.07 \mathrm{~kg}$ $\mathrm{ha}^{-1}$. These results allow us to infer that while there are populations adapted to the region, none was superior when compared with the performance of hybrids. Araújo and Nass
(2002) reported that, in general, the landrace populations are less productive than the commercial cultivars. However, these populations are important for presenting source of genetic variability that can be explored in the search for tolerant and/or resistant genes to biotic and abiotic factors. In addition, these varieties can offer a better cost benefit to smaller farmers, because they do not need the finance expense for the purchase of seeds and they have lower technological demand (inputs and management).

\section{Multivariate analysis of variance (MANOVA)}

In the multivariate variance analysis (MANOVA) significant differences $(p<0.01)$ between the mean vectors of varieties were also highlighted (Table 3). Accordingly, with rejection of the hypothesis that the mean vectors of varieties are equal is based on the use of other multivariate techniques with the purpose of size reduction or in other words discarding less relevant character.

\section{Canonical variables analysis}

The eigenvalues (percentage variances and cumulative variances) of the canonical variables, related to 15 analyzed characters analyzed, were shown in Table 3. It can be seen that the first two canonical variables $\left(\mathrm{CV}_{1}\right)$ explained $68.03 \%$ of the overall variation in available data set. Cruz et al. (2012) reported that if first two variables do not add up to $80 \%$ of the total variation, it becomes necessary to use the third canonical variable $\left(\mathrm{CV}_{3}\right)$, or even the fourth canonical variable. In this research, as the first three canonical variables reached $79.5 \%$ of the variation, the graphic dispersion results were analyzed based on the canonical variables $\mathrm{CV}_{1}, \mathrm{CV}_{2}$ and $\mathrm{CV}_{3}$.

The dispersion of genotypes graph prepared based on the first three canonical variables (Fig 1). We observed formation of three groups: group I formed by the varieties: Argentino Amarelo, Branco, Amarelão, Branco 8 Carreiras, Branco Roxo Índio, Caiano Rajado, Criolão and Dente de Ouro. The group II consisted only of commercial hybrids, and belonging AS 1551, BRSPlanalto, Coodetec 308 and AS 3466. The group III formed in isolation only variety Caiano Branco. Coimbra et al. (2010) analyzed four commercial hybrids and twelve populations of open-pollinated corn and also noted the distances between the traditional corn populations with new released cultivars. The same authors also report that in many areas the corn landrace populations are grown in marginal areas due to their adaptation to the specific conditions of these areas, or due to their use as raw material for specific food products, for cultural reasons and especially for some subsistence farmers, where the purchase of hybrid varieties seeds becomes an infeasible practice. Miranda et al. (2007) reported that maize landraces of small farmers are increasingly different in relation to agronomic important characteristics of the cultivars used in higher input systems.

The study of genetic distance through the canonical discriminant analysis enables the study of dissimilarity through the geometric distances between genotypes in scatter plots. It also allows the disposal of those characteristics that contribute minor effects to the genetic variability between the set of genotypes. The result of the relative importance of the analyzed variables in genetic distance is displayed in Table 4 . We found that the lowest characters in disposal order with greater ponderation character in the last canonical variables were: ED, GWE, NRE, NB, EL, SD, TL and HGW. However, only the characters LT, SD and EL may be 
Table 1. Resume univariate variance analysis (ANOVA) for 15 agronomic traits, length tassel (LT), number of tassel branches (NB), tassel weight (TW), leaf angle (LA), ear insertion height (EH), plant height (PH), stem diameter (SD), grain yield of the plot (GY), ear diameter (ED), ear length (EL), number of grains row per ear (NRE) number of grains per row (NGR), number of grains per ear (NGE), grains weight per ear (GWE) and hundred grains weight (HGW) evaluated at nine landraces and four comercial corn varieties.

\begin{tabular}{|c|c|c|c|c|c|}
\hline \multirow{2}{*}{ Characters } & \multicolumn{3}{|c|}{ Mean Square } & \multirow{2}{*}{ Average } & \multirow{2}{*}{$\mathrm{CV}(\%)$} \\
\hline & Blocks & Genotypes & Residue & & \\
\hline$\overline{\mathrm{TL}}$ & 12.336 & $39.870 * *$ & 5.370 & 32.82 & 7.06 \\
\hline NB & 9.662 & $84.464 * *$ & 6.680 & 13.99 & 18.48 \\
\hline TW & 1.263 & $23.774 * *$ & 1.311 & 7.80 & 14.68 \\
\hline LA & 5.435 & $164.882 * *$ & 5.800 & 29.87 & 8.06 \\
\hline $\mathrm{EH}$ & 128.610 & $1534.349 * *$ & 56.362 & 125.17 & 6.00 \\
\hline $\mathrm{PH}$ & 164.950 & $2522.775^{* *}$ & 98.552 & 248.44 & 4.00 \\
\hline SD & 5.561 & $14.841 * *$ & 3.067 & 23.70 & 7.39 \\
\hline GY & 1326864.75 & $26160567.29 * *$ & 736703.38 & 7285.19 & 11.78 \\
\hline ED & 1.710 & $70.447 * *$ & 2.992 & 44.84 & 3.86 \\
\hline EL & 0.342 & $5.787 * *$ & 0.914 & 16.98 & 5.63 \\
\hline NRE & 0.497 & $20.317 * *$ & 0.785 & 11.68 & 7.58 \\
\hline NGR & 19.757 & $38.895^{* *}$ & 6.508 & 35.99 & 7.09 \\
\hline NGE & 878.135 & $30964.573 * *$ & 1469.013 & 419.30 & 9.14 \\
\hline GWE & 3539.964 & $4150.776^{* *}$ & 256.793 & 175.45 & 9.13 \\
\hline $\mathrm{HGW}$ & 5.088 & $279.685^{* * *}$ & 8.325 & 40.79 & 7.07 \\
\hline
\end{tabular}

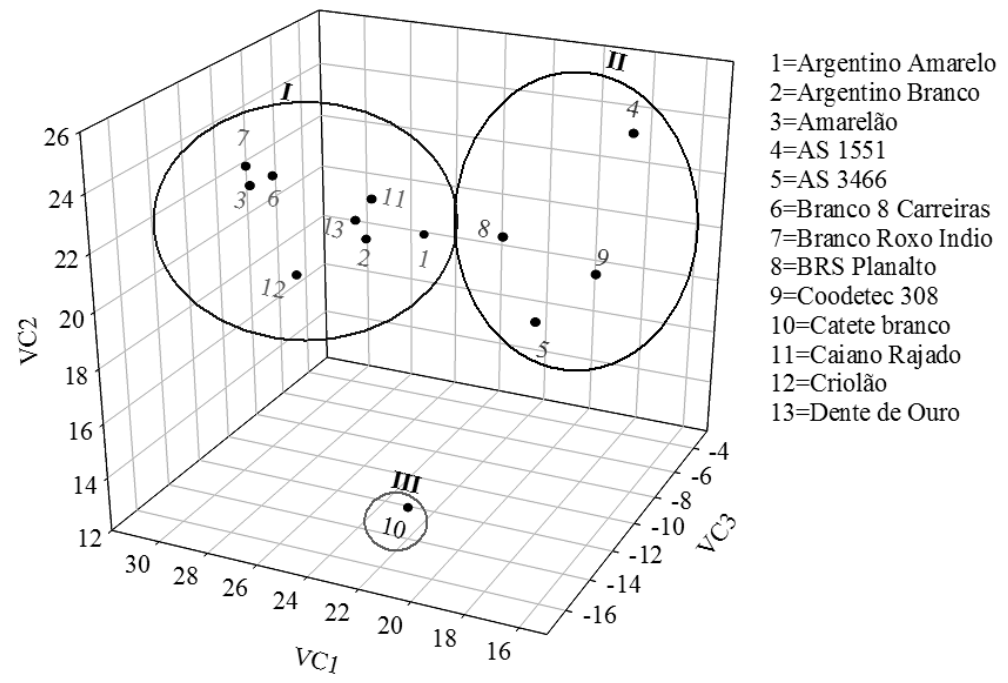

Fig 1. Dispersion of score graphics in relation to representative axes of the canonical variables (CV1, CV2 and CV3), on 15 traits evaluated in nine landraces and four commercial varieties.

discarded for not having great importance in the first three canonical variables and no distortion in the clustering process by Tocher optimization method (Table 5). These data corroborate to those found by Rotelli et al. (2012) showing that EL has a minor contribution to the genetic dissimilarity in 81 genotypes, 70 populations and 11 commercial checks of corn. Miranda et al. (2003) reported that the essential characteristics in genetic distance studies are those with small variation between the genotypes for presenting correlation with other characteristics.

Due to significance of variance data revealed in the univariate variance analysis and high ponderation coefficients in the first three canonical variables, we recognised the characteristics that may be considered discriminating like LA, EH, PH, GY, NRE and HGW. These would be the most efficient characters in the discrimination process between corn genotypes in question.

Some studies proved the efficiency of morphological and agronomic variables in the discrimination of maize genotypes. By analyzing the genetic dissimilarity between four and twelve hybrid populations of open pollination, it was found that the characters that contributed most to the genetic distance between varieties were number of grain rows per ear and ear diameter (Coimbra et al., 2010). Azar et al. (2012) used 13 agronomic traits to analyze the genetic dissimilarity among 30 maize inbred lines and found that the ear diameter might be used for determining genotypic discrimination between the set of lineages. Ganesan et al. (2010) analyzed a germplasm with 105 indigenous corn accessions and revealed that the characters plant height, number of grains rows per ear and ear height had higher contribution in determining the genetic distance between these varieties.

Tocher cluster analysis and genetic dissimilarity Mahalanobis

Besides the visual dispersion of scores in cartesian graphs (Fig 1), the agrupment analysis by the Tocher method established 
Table 2. Mean value for characteristics in nine landraces varieties and four commercial corn varieties and result of applying the Scott \& Knott test for 15 agronomic traits, length tassel (LT), number of tassel branches (NB) tassel weight (TW), leaf angle (LA), ear insertion height (EH), plant height (PH), stem diameter (SD), grain yield of the plot (GY), ear diameter (ED) ear length (EL), number of grains rows per ear (NRE), number of grains per row (NGR), number of grains per ear (NGE), grain weight per ear (GWE) and hundred grains weight (HGW).

\begin{tabular}{|c|c|c|c|c|c|c|c|c|c|c|c|c|c|c|c|}
\hline \multirow{3}{*}{ Genotype } & \multicolumn{15}{|c|}{ Characters $^{(2)}$} \\
\hline & $\mathrm{TL}$ & NB & TW & LA & $\mathrm{EH}$ & $\mathrm{PH}$ & SD & GY & ED & EL & NRE & NGR & NGE & GWE & HGW \\
\hline & $(\mathrm{cm})$ & (u) & (g) & & $(\mathrm{cm})$ & $(\mathrm{cm})$ & $(\mathrm{mm})$ & $\left(\mathrm{Kg} \mathrm{ha}^{-1}\right)$ & $(\mathrm{mm})$ & $(\mathrm{cm})$ & (u) & (u) & (u) & $-(\mathrm{g})$ & $(\mathrm{g})$ \\
\hline $1^{(1)}$ & $31.53 \mathrm{~b}$ & $12.00 \mathrm{c}$ & $5.89 \mathrm{c}$ & $32.11 \mathrm{~b}$ & $152.04 \mathrm{a}$ & $267.10 \mathrm{a}$ & $24.65 \mathrm{a}$ & $5448.41 \mathrm{e}$ & $36.48 \mathrm{~d}$ & $17.71 \mathrm{~b}$ & $10.50 \mathrm{c}$ & $37.83 \mathrm{a}$ & $394.67 \mathrm{c}$ & $127.61 \mathrm{c}$ & $32.82 \mathrm{~d}$ \\
\hline 2 & $30.50 \mathrm{~b}$ & $13.09 \mathrm{c}$ & $6.98 \mathrm{c}$ & $32.50 \mathrm{~b}$ & $127.63 \mathrm{c}$ & $254.43 \mathrm{~b}$ & $23.35 \mathrm{~b}$ & $5591.28 \mathrm{e}$ & $40.94 \mathrm{c}$ & $16.08 \mathrm{c}$ & $10.87 \mathrm{c}$ & $34.73 \mathrm{~b}$ & $379.76 \mathrm{c}$ & $144.20 \mathrm{c}$ & $40.46 \mathrm{c}$ \\
\hline 3 & $36.25 \mathrm{a}$ & $13.33 \mathrm{c}$ & $8.04 \mathrm{~b}$ & $33.81 \mathrm{~b}$ & $129.71 \mathrm{c}$ & $259.07 \mathrm{a}$ & $24.97 \mathrm{a}$ & $7046.04 \mathrm{~d}$ & $45.73 \mathrm{~b}$ & $17.61 \mathrm{~b}$ & $9.50 \mathrm{~d}$ & $35.82 \mathrm{a}$ & $338.92 \mathrm{~d}$ & $190.45 b$ & $51.89 \mathrm{a}$ \\
\hline 4 & $33.14 \mathrm{a}$ & $6.40 \mathrm{~d}$ & $4.07 \mathrm{~d}$ & $18.43 \mathrm{e}$ & $110.88 \mathrm{~d}$ & $241.23 \mathrm{~b}$ & $21.00 \mathrm{~b}$ & $10295.40 \mathrm{a}$ & $47.17 \mathrm{a}$ & $16.64 \mathrm{c}$ & $13.83 \mathrm{a}$ & $38.67 \mathrm{a}$ & $534.87 \mathrm{a}$ & $206.52 \mathrm{a}$ & $35.90 \mathrm{~d}$ \\
\hline 5 & $33.32 \mathrm{a}$ & $13.33 \mathrm{c}$ & $9.40 \mathrm{a}$ & $26.93 \mathrm{c}$ & $105.83 \mathrm{~d}$ & $226.16 \mathrm{c}$ & $21.85 \mathrm{~b}$ & $9425.58 \mathrm{~b}$ & $47.42 \mathrm{a}$ & $17.36 \mathrm{~b}$ & $13.17 \mathrm{~b}$ & $37.72 \mathrm{a}$ & $502.96 \mathrm{a}$ & $183.66 \mathrm{~b}$ & $35.45 \mathrm{~d}$ \\
\hline 6 & $36.14 \mathrm{a}$ & $14.17 \mathrm{c}$ & $7.01 \mathrm{c}$ & $32.71 \mathrm{~b}$ & $128.63 \mathrm{c}$ & $266.43 \mathrm{a}$ & $23.84 \mathrm{a}$ & $5924.62 \mathrm{e}$ & $44.52 \mathrm{~b}$ & $17.64 \mathrm{~b}$ & $9.33 \mathrm{~d}$ & $37.83 \mathrm{a}$ & $358.78 \mathrm{c}$ & $184.66 \mathrm{~b}$ & $47.74 \mathrm{~b}$ \\
\hline 7 & $31.18 \mathrm{~b}$ & $15.47 \mathrm{~b}$ & $10.12 \mathrm{a}$ & $30.61 \mathrm{~b}$ & $146.61 \mathrm{a}$ & $258.61 \mathrm{a}$ & $25.98 \mathrm{a}$ & $6891.28 \mathrm{~d}$ & $45.24 \mathrm{~b}$ & $16.61 \mathrm{c}$ & $9.33 \mathrm{~d}$ & $35.58 \mathrm{a}$ & $322.62 \mathrm{~d}$ & $184.09 \mathrm{~b}$ & $53.66 \mathrm{a}$ \\
\hline 8 & $34.33 \mathrm{a}$ & $13.91 \mathrm{c}$ & $10.35 \mathrm{a}$ & $24.73 \mathrm{~d}$ & $121.65 \mathrm{c}$ & $247.94 \mathrm{~b}$ & $24.42 \mathrm{a}$ & $10598.42 \mathrm{a}$ & $47.81 \mathrm{a}$ & $17.75 \mathrm{~b}$ & $13.67 \mathrm{a}$ & $37.83 \mathrm{a}$ & $515.33 \mathrm{a}$ & $203.51 \mathrm{a}$ & $37.87 \mathrm{c}$ \\
\hline 9 & $28.50 \mathrm{c}$ & $9.34 \mathrm{~d}$ & $4.64 \mathrm{~d}$ & $24.50 \mathrm{~d}$ & $99.56 \mathrm{~d}$ & $221.20 \mathrm{c}$ & $22.18 \mathrm{~b}$ & $9194.44 \mathrm{~b}$ & $49.11 \mathrm{a}$ & $16.28 \mathrm{c}$ & $14.19 \mathrm{a}$ & $33.33 \mathrm{~b}$ & $485.58 \mathrm{a}$ & $196.00 \mathrm{a}$ & $35.86 \mathrm{~d}$ \\
\hline 10 & $32.08 \mathrm{~b}$ & $17.87 \mathrm{~b}$ & $7.99 \mathrm{~b}$ & $37.57 \mathrm{a}$ & $105.83 \mathrm{~d}$ & $202.55 \mathrm{~d}$ & $22.18 \mathrm{~b}$ & $3662.07 \mathrm{f}$ & $43.79 \mathrm{~b}$ & $16.11 \mathrm{c}$ & $12.50 \mathrm{~b}$ & $29.50 \mathrm{c}$ & $361.50 \mathrm{c}$ & $128.30 \mathrm{c}$ & $35.42 \mathrm{~d}$ \\
\hline 11 & $34.69 \mathrm{a}$ & $18.26 \mathrm{~b}$ & $8.82 \mathrm{~b}$ & $28.34 \mathrm{c}$ & $129.41 \mathrm{c}$ & $266.77 \mathrm{a}$ & $25.32 \mathrm{a}$ & $8008.04 \mathrm{c}$ & $47.10 \mathrm{a}$ & $16.93 \mathrm{c}$ & $12.50 \mathrm{~b}$ & $36.51 \mathrm{a}$ & $444.67 \mathrm{~b}$ & $188.13 b$ & $40.53 \mathrm{c}$ \\
\hline 12 & $35.79 \mathrm{a}$ & $13.71 \mathrm{c}$ & $9.23 \mathrm{a}$ & $35.98 \mathrm{a}$ & $131.07 \mathrm{c}$ & $250.16 b$ & $25.39 \mathrm{a}$ & $6628.24 \mathrm{~d}$ & $41.89 \mathrm{c}$ & $18.92 \mathrm{a}$ & $9.83 \mathrm{~d}$ & $38.00 \mathrm{a}$ & $374.33 \mathrm{c}$ & $171.68 \mathrm{~b}$ & $46.04 \mathrm{~b}$ \\
\hline 13 & $29.20 \mathrm{c}$ & $20.94 \mathrm{a}$ & $8.84 \mathrm{~b}$ & $30.02 \mathrm{~b}$ & $138.39 \mathrm{~b}$ & $268.09 \mathrm{a}$ & $23.02 \mathrm{~b}$ & $5993.66 \mathrm{e}$ & $45.72 \mathrm{~b}$ & $15.14 \mathrm{c}$ & $12.67 \mathrm{~b}$ & $34.51 \mathrm{~b}$ & $436.94 \mathrm{~b}$ & $172.00 \mathrm{~b}$ & $36.68 \mathrm{~d}$ \\
\hline
\end{tabular}

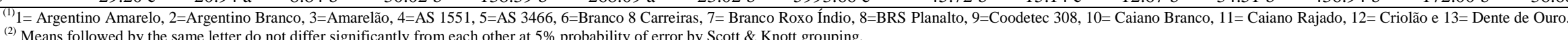

Table 3. Summary of multivariate variance analysis (MANOVA), through four statistical tests, indicating the probabilaty of F-test for 15 variables. It simultaneously estimates variance ( $\lambda$ eigenvalues) associated with the canonical variables (CV), percentage and accumulated variances, obtained from 15 traits evaluated in nine landraces and four commercial varieties.

\begin{tabular}{|c|c|c|c|c|}
\hline Statistical test & & Value & F value & $\operatorname{Pr}>\mathrm{F}$ \\
\hline Lambda de Wilks & & 0.000002 & 7.82 & 0.0001 \\
\hline Pillai's Trace & & 5.887269 & 3.66 & 0.0001 \\
\hline Hotelling-Lawley & & 57.182864 & 14.09 & 0.0001 \\
\hline \multirow[t]{3}{*}{ Roy's Greatest Root } & & 27.004308 & 102.62 & 0.0001 \\
\hline & \multicolumn{4}{|c|}{ Canonical variables } \\
\hline & Variance ( $\lambda$ eigenvalues) & Variance $(\%)$ & Accumul & nce $(\%)$ \\
\hline CV1 & 22.502 & 47.222 & 47.222 & \\
\hline CV2 & 9.915 & 20.808 & 68.030 & \\
\hline CV3 & 5.472 & 11.483 & 79.513 & \\
\hline CV4 & 4.630 & 9.717 & 89.230 & \\
\hline CV5 & 2.850 & 5.981 & 95.211 & \\
\hline CV6 & 1.293 & 2.713 & 97.925 & \\
\hline CV7 & 0.397 & 0.833 & 98.757 & \\
\hline CV8 & 0.269 & 0.565 & 99.322 & \\
\hline CV9 & 0.167 & 0.351 & 99.673 & \\
\hline CV10 & 0.109 & 0.230 & 99.903 & \\
\hline CV11 & 0.037 & 0.077 & 99.979 & \\
\hline CV12 a CV15 & 0.010 & 0.021 & 100.000 & \\
\hline
\end{tabular}


Table 4. Estimate of coefficients of ponderation associated with canonical variables, obtained from 15 characters evaluated in nine landrace varieties and four comercial varieties.

\begin{tabular}{|c|c|c|c|c|c|c|c|c|c|c|c|c|c|c|c|}
\hline \multirow{2}{*}{$\begin{array}{l}\text { Canonical } \\
\text { Varieties }\end{array}$} & \multicolumn{15}{|c|}{ Characters } \\
\hline & TL & NB & TW & LA & EH & $\mathrm{PH}$ & SD & GY & ED & EL & NRE & NGR & NGE & GWE & HGW \\
\hline CV1 & 0.060 & 0.145 & 0.106 & 0.379 & 0.350 & 0.208 & 0.113 & -0.446 & -0.098 & -0.025 & -0.301 & 0.049 & 0.018 & -0.071 & 0.578 \\
\hline CV2 & 0.082 & -0.164 & -0.017 & -0.438 & 0.141 & 0.313 & -0.095 & 0.466 & 0.226 & -0.031 & -0.175 & 0.350 & -0.065 & 0.163 & 0.442 \\
\hline CV3 & -0.189 & -0.193 & -0.380 & -0.242 & 0.475 & 0.152 & -0.143 & -0.061 & -0.522 & -0.085 & 0.137 & 0.026 & -0.163 & -0.331 & -0.124 \\
\hline CV4 & -0.085 & 0.470 & 0.370 & -0.007 & 0.155 & 0.292 & 0.002 & 0.008 & 0.021 & -0.223 & 0.446 & 0.428 & 0.219 & -0.082 & -0.193 \\
\hline CV5 & 0.356 & -0.250 & 0.444 & 0.116 & 0.183 & -0.124 & 0.115 & 0.221 & -0.316 & 0.560 & -0.010 & 0.207 & 0.016 & -0.135 & -0.119 \\
\hline CV6 & 0.566 & -0.079 & -0.409 & 0.133 & -0.314 & 0.470 & -0.098 & -0.185 & 0.063 & 0.086 & 0.017 & 0.198 & 0.134 & -0.163 & -0.172 \\
\hline CV7 & 0.113 & 0.182 & -0.183 & -0.018 & 0.322 & 0.180 & 0.632 & 0.206 & 0.353 & 0.152 & 0.134 & -0.343 & -0.144 & -0.176 & -0.089 \\
\hline CV8 & -0.538 & -0.096 & -0.053 & 0.433 & -0.118 & 0.340 & 0.024 & 0.386 & -0.024 & 0.096 & -0.337 & 0.035 & 0.235 & -0.166 & -0.159 \\
\hline CV9 & 0.026 & -0.254 & 0.060 & 0.143 & -0.338 & 0.156 & 0.271 & 0.203 & -0.365 & -0.223 & 0.501 & -0.209 & 0.058 & 0.031 & 0.419 \\
\hline CV10 & -0.031 & -0.078 & -0.228 & 0.293 & 0.363 & 0.080 & -0.253 & 0.032 & 0.067 & 0.269 & 0.335 & -0.095 & 0.183 & 0.648 & -0.022 \\
\hline CV11 & -0.342 & 0.227 & -0.244 & -0.232 & -0.292 & -0.010 & 0.319 & -0.230 & -0.164 & 0.535 & 0.085 & 0.330 & -0.060 & 0.152 & 0.148 \\
\hline CV12 & 0.136 & 0.327 & -0.398 & 0.352 & 0.027 & -0.489 & -0.092 & 0.383 & -0.026 & -0.073 & 0.091 & 0.301 & -0.080 & -0.204 & 0.212 \\
\hline CV13 & 0.062 & 0.026 & -0.130 & -0.289 & 0.101 & -0.210 & 0.090 & 0.001 & -0.047 & 0.024 & -0.077 & -0.130 & 0.880 & -0.133 & 0.119 \\
\hline CV14 & -0.058 & -0.493 & -0.102 & 0.132 & 0.126 & -0.213 & 0.466 & -0.174 & 0.155 & -0.333 & -0.011 & 0.469 & 0.068 & 0.160 & -0.178 \\
\hline CV15 & -0.232 & -0.330 & 0.068 & 0.049 & -0.002 & -0.081 & -0.250 & -0.185 & 0.497 & 0.251 & 0.379 & 0.037 & 0.015 & -0.469 & 0.230 \\
\hline
\end{tabular}

Table 5. Optimization grouping obtained by Tocher method and average distance intergroups, among nine landraces and four commercial corn varieties, based on 15 characters, using the Mahalanobis distance.

\begin{tabular}{|c|c|c|c|c|c|c|}
\hline \multicolumn{7}{|c|}{ Grouping by Tocher } \\
\hline Groups & Varieties ${ }^{(1)}$ & & & & & \multirow{4}{*}{1} \\
\hline $\mathrm{I}$ & 3 & 6 & 7 & 122 & 1113 & \\
\hline II & 5 & 8 & 9 & 4 & & \\
\hline III & 10 & & & & & \\
\hline \multicolumn{7}{|c|}{ Average distance intergroups } \\
\hline Groups & & $\bar{I}$ & & II & III & \\
\hline $\bar{I}$ & & - & & & & \\
\hline II & & 114,824 & & - & & \\
\hline III & & 111,601 & & 129,339 & - & \\
\hline
\end{tabular}

(1) $1=$ Argentino Amarelo, $2=$ Argentino Branco, 3= Amarelão, 4= AS 1551, 5= AS 3466, 6= Branco 8 Carreiras, 7= Branco Roxo Índio, 8= BRS Planalto, 9= Coodetec 308, 10= Caiano Branco, 11= Caiano Rajado, 12= Criolão e 13= Dente de Ouro. 
groups with a degree of intragroup homogeneity and heterogeneity inter-group, based on the Mahalanobis matrix (Table 5).

We observed correlation between canonical variate analysis and Tocher optimization method. All varieties that proved different in three dimensional space of Fig 1, also showed up in different groups I, II and III of Tocher analysis. These results confirmed the consistency of the methods for disposal of the characters, in relation to the study of genetic distance. Therefore, the minor characters TL, SD, and EL were discarded.

The dissimilarity between intergroups (Table 5) obtained also by Tocher optimization method which made it possible to differentiate between the formed groups with more genetic difference. The highest average distances between groups were obtained between groups II and III (129.3). In contrast, groups I and II (111.6) showed the lowest average distances among groups, which can be explained by the fact that both groups are formed by landrace populations, coming from the same region edaphoclimatic cultivation. Landraces are created in large part by the maintenance of seed and/or selection after generations of cultivation by farmers, through old or even recent cross breeding, or simply by intrapopulation selection of more adapted to the plant growing systems (Ferreira et al., 2009). The results related to intra and inter-group distances may indicate that populations can be a source of inbred lines for hybridization. It might be due to cross breeeding between more genetically distant individuals which increase the chances of success in obtaining heterosis, or in choosing more different populations to the cross breeding and launching new open pollinated varieties.

Also, it is noteworthy the possibility of extracting promising lineages within each group; thereby, forming heterotic groups. So, different groups present genetic dissimilarity and tend to have higher heterosis in hybrid combinations between lineages of groups. In plant breeding programs with an emphasis on obtaining hybrids, it is important to choose different lineages, which have standard agronomic and present genetic complementarity for greater heterosis results (Simon et al., 2012).

According to the results of this work, for the creating new intervarietal hybrids or obtaining superior inbred lines adapted to soil and climatic conditions of southern of Rio Grande do Sul region, the crosses between varieties that are allocated in the larger groups with higher yield of grain of group I (AS 1551, BRSPlanalto, AS 3466 and Coodetec 308) and higher yield of grain of group II (Amarelão, Branco Roxo Índio, Caiano Rajado e Criolão) are suggested. The landrace Caiano Branco, despite being more dissimilar than the other, is not recommended for use in hybridization schemes or selection due to its unfavorable characteristics such as low GY, NRE and present themselves in groups of smaller EL, GWE and HGW. However, this population with lower PH and EH can be important source of genes/alleles favorables for selection of populations/strains to reduce plant height. Taller plants with high inserted ears can cause increased susceptibility to lodging and may sometimes not be suitable for cultivation in areas with high-wind events and to farmers working with high nitrogen doses (Paixão et al., 2008).

The evaluation of landrace populations has high importance for farmers who use them regularly. Also they are very important for hybridization in breeding programs. The breeding population or obtaining hybrids intervarietals from dissimilar populations should be considered, either for maintenance of genetic variability or for the use by farmers. Therefore, the use of landrace populations and the selection of hybrid combinations, presenting complementary characteristics are essential. According to Araújo et al. (2002), landrace populations have specific genes/alleles of interest, especially with regard to regional conditions with specific biotic and abiotic stress importance in maize culture.

\section{Materials and methods}

\section{Plant materials}

The experiment was conducted in the experimental area of the Center for Genomics and plant breeding, Federal University of Pelotas - UFPel, located in the municipality of Capão do Leão-RS. The geographic coordinates of this city are latitude $31^{\circ} 45^{\prime} \mathrm{S}$, longitude $52^{\circ} 29^{\prime} \mathrm{O}$, altitude of $13 \mathrm{~m}$, soil classified as Dystrophic Argisol red and yellow (Santos et al., 2006).

Were used commercial varieties of corn and landraces, including a simple hybrid (AS 1551), a triple hybrid (AS 3466), a double hybrid (Coodetec 308), a synthetic (BRS Planalto) and nine landraces populations (Argentino Amarelo, Argentino Branco, Amarelão, Branco 8 Carreiras, Branco Roxo Índio, Caiano Branco, Caiano Rajado, Criolão e Dente de Ouro) maintained by farmers belonging to UNAIC (Union of community associations from inside of Canguçu), located in the municipality of Canguçu-RS.

\section{Experimental design and experimental procedure}

The experimental units were composed of two lines each with five meters in length, spaced with 0.70 meters. The fertilizer sowing consisted of $200 \mathrm{Kg} \mathrm{ha}^{-1}$ of N-P-K, formulation 5-2020. The topdressing was held at V3-V5 stage with $150 \mathrm{~kg} \mathrm{ha}^{-1}$ of nitrogen using urea as source. The sowing was carried out according to the agro-climatic zoning of the local. The soil management and crop treatments were performed according to the phenological stages and the need of the culture. After emergence and establishment the hand thinning was used to stand setting of 42 plants per plot, equivalent to 60,000 plants per hectare. These hybrids/populations were evaluated in the $2012 / 13$ crop years, in an experiment conducted in a randomized block design with six replications.

\section{Traits measured}

The evaluated traits were: tassel lenght (TL in centimeters), number of tassel branches (NB, in units), tassel weight (TW, in grams), leaf angle (LA, in degrees), insertion ear height (EH in centimeters), plant height ( $\mathrm{PH}$ in centimeters), stem diameter (SD in millimeters), grain yield (GY, in kg per plot), ear diameter (ED in millimeters), ear length (EL in centimeters), number of grains rows per ear (NRE in units), number of grains per row (NGR in units), number of grains per ear (NGE in units), grains weight per ear (GWE in grams) and 100 grains weight (GWE in grams).

\section{Statistical analysis}

Data were subjected to analysis of variance (ANOVA), and later held the grouping means by the Scott $\&$ Knott method at $5 \%$ probability for the characters that proved significant in the variance analysis. Then, the multivariate variance analysis (MANOVA) was applied to evaluate the difference between the mean treatments vectors using the criteria of Wilks Lambda, Pillai's Trace, Hotelling-Lawley and Roy's Greatest Root. 
Estimates of canonical discriminant analysis was obtained from data processed by a set of pivotal condensation process where new Zis characters represent the residual covariance matrices equal to zero and a variance equal to one (Cruz et al., 2012). As evidenced in the first canonical variables, the concentration of much of the all total variance, generally referenced as $80 \%$ or above, carried out the study of genetic variability by ways of the geometrical distances between hybrids/populations scatterplots, whose coordinates are related scores to the first three canonical variables. The first three canonical variables were plotted in 3D scatter plot.

The characters disposal study is based on the principle that the relative importance of canonical variables decreases from the first to the last, since the latter variables are responsible for explanation of a minimum percentage of the total variance available. Thus, the character revealed weighting coefficients of greater magnitude in absolute value in the last canonical variables was considered minor to explain the total variation and; therefore, subjected to disposal analysis (Cruz et al., 2012).

After identification of characters of higher weightings in the lattest canonical variables and subject to disposal, a reanalysis of the set of remaining characters was performed. Based on the generalized Mahalanobis distance matrix $\left(\mathrm{D}^{2}\right)$ from the standardized averages, the Tocher optimization method (Rao, 1952) was applied until it no more distortion in the formation of groups was observed. Analyses were performed using the Genes programs (Cruz, 2013) and SAS (Statistical Analysis System, 2013).

\section{Conclusion}

There is genetic dissimilarity between nine landrace populations and four commercial corn hybrids, forming three distinct groups with the use of multivariate analysis techniques based on canonical discriminant analysis and grouping by Tocher. The most important characters in the discrimination of genetic distance between varieties are: leaf angle, ear insertion height, plant height, grain yield, number of grain rows of ear and 100 grains weight. The varieties AS 1551, BRS Planalto, AS 3466, Coodetec 308, Amarelão, Branco Roxo Índio, Caiano Rajado and Criolão presented high yield grains, which emphasised the incorporation of such genotypes in maize breeding programs.

\section{Acknowledgements}

The authors thank the Higher Education Personnel Improvement Coordination (CAPES) for project financing and the granting of the first author's doctoral fellowship.

\section{References}

Araújo PM, Nass LL (2002) Caracterização e avaliação de milho crioulo. Sci Agri. 59: 589-593.

Azad Mak, Biswas BK, Alam N, Alam SS (2012) Genetic diversity in maize (Zea mays L.) inbred lines. Blanja J. 10: 64-70.

Boef WS. Biodiversidade e agrobiodiversidade (2007) In: BOEF, W. S. et al. (Org.) Biodiversidade e agricultores: fortalecendo o manejo comunitário. Porto Alegre: L\&PM, 2: $36-40$.

Cruz CD (2013) GENES - a software package for analysis in experimental statistics and quantitative genetics. Acta Sci. 35: 271-276.
Cruz CD, Regazzi AJ, Carneiro PCS (2015) Modelos biométricos aplicados ao melhoramento genético. $4^{\mathrm{a}}$ ed.Viçosa: UFV:514.

Coimbra RR, Miranda GV, Cruz CD, De Melo AV, Eckert FR (2010) Caracterização e divergência genética de populações de milho resgatadas do sudeste de Minas Gerais. Sci Agri. 41: 159-166.

Dotto MA, Afférri FS, Peluzio JM, Melo AV, Carvalho EV (2010) Divergência genética entre cultivares comerciais de milho em baixas altitudes no Tocantins, safra 2007/2008. RCA. 41(4):630-637

Ferreira JM, Moreira RMP, Hidalgo JAF (2009) Capacidade combinatória e heterose em populações de milho crioulo. Cien Rural. 39: (2)332-339

Ganesan KN, Nallathambi G, Safawo T, Senthil N, Tamilarasi PM (2010) Genetic divergence analysis in indigenous maize germplasms (Zea mays L.). Eletron J Plant. 1(4):1241-1243.

Hallauer AR, Carena MJ, Miranda Filho JB de (2010) Quantitative genetics in maize breeding. Springer. 663.

Miranda GV, De Souza LV, Dos Santos IC, Mendes FF (2007) Resgate de variedades crioulas de milho na região de Viçosa-MG. Rev Bra Agroecol. 2(1): 1145-1148.

Miranda GV, Coimbra RR, Godoy CL, Souza LV, Guimarães LJM, Melo AD (2003) Potencial de melhoramento e divergência genética de cultivares de milho-pipoca. Pesqui Agropec Bras. 38(6):681-688.

Moura WDM,; Casali VWD, Cruz CD, Lima PD (1999) Divergência genética em linhagens de pimentão em relação à eficiência nutricional de fósforo. Pesqui Agropec Bras. 34(2):217-224.

Nass LL, Pellicano LJ, Valois ACC. (1993) Utilization of genetic resources for maize and soybean breeding in Brazil. Braz J Genet. 16: 983-988.

Paixão SL, Cavalcante M, Ferreira PV, Da Silva Madalena JA, Pereira RG (2008) Divergência genética e avaliação de populações de milho em diferentes ambientes no estado de Alagoas. RC. 21(4): 191-195.

Rao RC (1952) Advanced statistical methods in biometrics research. New York: John Wiley and Son: 390.

Reddy SM, Kumar SS, Sudharshan MR, Kumar KV (2013) Divergence in Baby Corn (Zea mays L.). International J Innov Res Develop. 2(8).

Rotili EA, Cancellier LL, Dotto MA, Peluzio JM, Carvalho EVD (2012) Divergência genética em genótipos de milho, no Estado do Tocantins. Rer Ciênc Agron. 43(3): 516-521

Santos HG, Jacomine PKT, Anjos LHC, Oliveira VA, Oliveira JB, Coelho MR, Lumbreras JF, Cunha TJF (2006) Sistema brasileiro de classificação de solos. Rio de Janeiro: Embrapa Solos. 306p.

SAS Institute (2003) SAS 9. 3 Output Delivery System: User's Guide. SAS institute.

Simon GA, Kamada T, Moiteiro M (2012) Divergência genética em milho de primeira e segunda safra. Semina Agra. 33(2):44 